\title{
Silent Transmission of HTLV-2 in an Endemic Area of Northeastern Brazil: Report of 10 Cases and Review Literature
}

\section{Graça Maria de Castro Viana ${ }^{1 *}$, Helaine Dias Guimarães², Saphyra Medeiros Salem ${ }^{2}$, Augusto Viana Arouche Santos ${ }^{3}$ and Jamilly Gonçalves Zani ${ }^{3}$}

\author{
${ }^{1}$ Department of Pathology, Post-graduation Program in Adult Health, Federal University of Maranhão, \\ Brazil \\ ${ }^{2}$ Academics of Medicine, Federal University of Maranhão, Brazil \\ ${ }^{3}$ Academics of Medicine, University Metropolitan Center of the Amazon, Brazil
}

*Corresponding author: Graça Maria de Castro Viana, Department of Pathology, Post-graduation Program in Adult Health, Federal University of Maranhão, Rua Mitra, n14, Ed. Rafael Sobrinho, Apt 401, Renascença II, São Luís, Maranhão, Brazil, Tel: 55-98-3223-1314; 55-98-98491-2424

\begin{abstract}
HTLV 2 is endemic among Amerindians and has been reported in intravenous drug abusers in the USA, Europe, and Asia. The most important indigenous communities in Brazil are distributed in the states of Amapá, Pará, Amazonas, Roraima, Rondônia and Maranhão. This study aims to determine the prevalence of HTLV-2 in the state of Maranhão. Ten patients attended at a referral hospital who presented confirmatory Western blot serology for HTLV-2 were analyzed. All seropositives were asymptomatic and using B-complex vitamins; they are not indigenous and deny use of drugs. An endemic transmission of HTLV 2 occurs in the state of Maranhão, although there is no significant population study, but it implies the need to specify the route of transmission of this virus in our region, which justifies the need for molecular studies with subtype typing involved for a better epidemiological understanding.
\end{abstract}

\section{Keywords}

HTLV-2 infection, Subtype, The Best Web Links

\section{Introduction}

Human T-cell lymphotropic viruses 1 and 2 (HTLV-1, HTLV-2), a member of the Retroviridae [1] family, infect lymphocytic cells, presenting the HTLV 1 preferential tropism for CD4+ cells and HTLV 2 for CD8+ cells [2].

HTLV-1 and HTLV-2 are similar, having $60 \%$ of the same sequence of nucleic acids and $70 \%$ in the same amino acid sequence [3].
HTLV $1 / 2$ virus transmission is performed vertically, which may occur during pregnancy, childbirth or later breastfeeding, the latter being the main mode of infection of the infant; or horizontally whose pathways are parenteral or sexual [4].

HTLV 1 is a pathology that affects multiple organs of the infected organism, presenting a clinical picture of dermatological, hematological alterations - Adult T Cell Leukemia/Lymphoma (LLTA) and other diseases such as tropical spastic paraparesis and HTLV-I associated myelopathy (PET/HAM) [4].

HTLV-2 has been sporadically associated with HAM/ TSP-like neurological disease, also seems to predispose to bacterial infections, due to immunological impairment, and is capable of producing cellular transformation. A chronic infection, but most of patients are asymptomatic [5].

HTLV-2 virus is considered ancestral on the American continent, with extensive distribution in indigenous groups in the Americas, and transmitted to the general population and injecting drug users from the indigenous population [3].

Type 2 virus infection is closely associated with drug users and indigenous populations. The prevalence of HTLV 2 contamination in the American Indian population is $37 \%$ (5.2 million); the rate of $0.23 \%$ in Mexico was

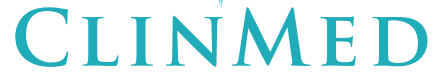

INTERNATIONAL LIBRARY
Copyright: (C) 2019 Viana GMC, et al. This is an open-access article distributed under the terms of the Creative Commons Attribution License, which permits unrestricted use, distribution, and reproduction in any medium, provided the original author and source are credited. 
observed among 440 indigenous peoples of the region [3]. The most relevant indigenous communities in Brazil are distributed in the States of Amapá, Pará, Amazonas, Roraima, Rondônia and Maranhão [5]. The state with the highest incidence of the disease is Amapá with approximately $80 \%$ of its indigenous population affected by type 2 of the disease [3]. The Brazilian Amazon region is the largest endemic area in the world for HTLV-2c, and subtype $2 b[6]$ is still present in this region. Subtype analysis is important in studies on the geographical origin and spread of viral isolates.

Maranhão is considered a state of high endemicity for HTLV, taking first place in incident of Brazil. In the $16^{\text {th }}$ and $17^{\text {th }}$ centuries, indigenous labor was part of the Maranhão economy; however, the African slave population was also part of the labor in the $17^{\text {th }}$ century [7], a condition that indigenous peoples, previously isolated, with the neo-Brazilian populations in formation. Sexual intercourse, particularly between indigenous men and non-indigenous women, is a common practice, especially among some Kayapó communities, which are located close to small towns maintained by commercial activities, agriculture, and mining [8].

Considering these aspects of Maranhão population dynamics, this study reports the prevalence of HTLV-2 in blood donors in the State of Maranhão.

\section{Case Report}

Serological screening for HTLV 1/2 (ELISA) performed by enzyme-linked immunosorbent assay (ELISA) at the Center of Hematology and Haemotherapy of Maranhão (HEMOMAR), which were later sent to the Hospital of Reference in Infectious and Parasitic Diseases of the State of Maranhão, Brazil. Patients voluntarily get tested for HTLV. HTLV-2 infection was confirmed by discriminatory Western Blot (GD21, p29, p36, and Rgp46II). Ten patients of HTLV-2 were diagnosed. Eight were women and two were males; the age group comprised 17 to 67 years (median 50 years). Only one case had a previous history of infection in the family. All not had history intravenous drug use and not were neither indigenous. One of them presented positive serology for both viruses (HTLV 1 and 2), with a history of blood transfusion, milk-breast-feeding and the mother was positive for HTLV 1. One case had HTLV-1 seropositive husband; another had HTLV negative husband, and in another, the spouse was HTLV in determined. Routine blood tests were normal. Neurological examination not revealed.

\section{Discussion}

The presence of HTLV-2 disease is rare, however, studies have demonstrated the presence of individuals with clinical manifestation similar to HAM/TSP. In 1993 was reported the first case of HTLV-2 infection associated with neurological disorder [9]. Unlike HTLV 1 , virus type 2 carriers have a lower pro-viral load, justifying low disease progression. In 2014 has related the first description of HAM/TSP-like illness caused by this HTLV-2 subtype that had not been identified before in Rio de Janeiro/Brazil [10]. Our paper unequivocally showed the presence of HTLV-2 infection of the State of Maranhão, all patients being asymptomatic, suggesting a silent transmission, unlike that described in Rio de Janeiro, where it was reported the first case of HAM/ TSP- like ilness caused by HTLV-2b, despite the low prevalence of infections due to this HTLV type in this city (Rio de Janeiro) of Brazil. The silent transmission occurs in society because HTLV-2 disease is normally asymptomatic as well as HTLV 1 and unknown.

\section{Conclusion}

These findings confirm that HTLV-2 infection of the State of Maranhão/Northeast of Brazil is very epidemiologically important, since a silent transmission occurs, which makes it difficult to specify the route of transmission of this virus in these patients. Thus, it is justified the need for molecular studies in the State of Maranhão to better understand the epidemiology of transmission of this virus in the population and to allow epidemiological control actions by state and municipal managers.

\section{Conflicts of Interest}

There are no conflicts of interest to declare.

\section{References}

1. Coffin JM (1996) Retroviridae The Viruses and their replication. In: Fiedls BN, Knipe DM, Howley PM, Chanock RM, Melnick JL, et al. Fundamental Virology. Lippincott Raven, Philadelphia, 763-843.

2. Tamegão-Lopes BP col, Priscila Rocha Rezende, Luciana Maria Cunha Maradei-Pereira, José Alexandre Rodrigues de Lemos (2006) Carga proviral do HTLV-1 e HTLV-2: Um método simples através da PCR quantitativa em tempo real. Revista da Sociedade Brasileira de Medicina Tropical 39: $548-552$

3. Paiva Arthur, Casseb Jorge (2015) Origin and prevalence of human t-lymphotropic virus type 1 (htlv-1) and type 2 (htlv2) among indigenous populations in the Americas. Rev Inst Med trop Sao Paulo 57: 1-13.

4. Gomes FVBAF, Eleutério Junior J (2011) HTLV II em doadores de sangue na Hemorrede do CearáEMOCE. Revista Associação Médica Brasília 57: 315-318.

5. Catalan-Soares, Bernadette Corrêa, Proietti, Bernadette Corrêa, Carneiro-Proietti, et al. (2001) Os vírus linfotrópicos de células T humanos (HTLV) na última década (19902000): Aspectos epidemiológicos. Rev bras epidemiol 4: 81-95.

6. Santos S, Ethienne Lobato dos (2009) Caracterização molecular do HTLV-1/2 em doadores de sangue em Belém, Estado do Pará: primeira descrição do subtipo HTLV-2b na região Amazônica. Rev Soc Bras Med 42: 271-276.

7. Silva, Maria Celeste Gomes da (2010) Rotas Negreiras e Comércio de Africanos para o Maranhão Colonial, 17551800. Departamento de História, Instituto de Ciências Humanas e Sociais, Universidade Federal Rural do Rio de Janeiro, Seropédica, RJ, 46. 
8. Vallinoto ACR, Ishak R (2017) HTLV-2: Uma infecção antiga entre os povos indígenas da Amazônia brasileira. Rev Pan-Amaz Saude 8.

9. Jacobson S, Lehky T, Nishimura M, Robinson S, McFarlin DE, et al. (1993) Isolation of HTLV-II from a patient with chronic, progressive neurological disease clinically indis- tinguishable from HTLV-I-associated myelopathy/tropical spastic paraparesis. Ann Neurol 33: 392-396.

10. Rosadas, Carolina, Zanella L, Cabral-Castro MJ, Peralta $\mathrm{JM}$, et al. (2014) Human T-lymphotropic virus type 2 subtype $b$ in a patient with chronic neurological disorder. $\mathrm{J}$ Neurovirol 20: 636-639. 